\title{
Conventional and organic cropping systems at Suitia II: Crop growth and yield
}

\author{
J. KORVA and E. VARIS \\ University of Helsinki, Department of Plant Husbandry \\ Viikki, SF-00710 Helsinki, Finland
}

\begin{abstract}
Crop yields between 1982 and 1988 are reported here as a part of a cropping system experiment carried out at Suitia, Southern Finland. The soil was silty clay. There were four conventional and four organic systems: conventional cropping systems for barley monoculture, cereal production, diverse plant production, or a cattle farm, and organic cropping systems either for plant production with or without composting, or for cattle farms with or without composting. The crop sequences were fixed by six-year rotations, carried out in two phases.

There were great differences in yields between the years, and the organic cropping systems were more negatively affected by poor growing conditions than the conventional ones. In the organic systems, the barley yields in 1985 and in 1988 were $25 \%$ of the yields obtained from conventional stands, when the latter yielded about $3 \mathrm{t} / \mathrm{ha}$. In better years, barley in the organic plant production yielded $50 \%$ of the yield obtained in conventional barley monoculture $(6 \mathrm{t} / \mathrm{ha})$. It was not possible to differentiate between the effects of two different causes - the preceeding crop and annual variation. The yields obtained with 'organic' winter wheat and oats ( + Vicia faba) were $40 \%$ of those from the respective conventional pure stands. The clover-grass leys of the organic systems yielded as much as the conventional grass leys until they were destroyed by water and the resulting ice cover during winter. Compared to those of 'conventional' system, the 'organic' system gave annual mean yields of potato varying from $37 \%$ of the $16 \mathrm{t} /$ ha obtained conventionally to $48 \%$ of the $21 \mathrm{t} /$ ha obtained conventionally.

Barley variety was found to interact with cropping system in 1988, a year characterised by draught stress. In 1989, in a separate trial carried out on the same field, an interaction between soil wetness (location) and cropping system was observed. Wetness of soil in winter seemed to interfere more severely in the organic system than in the conventional one. Because the uncontrolled variation of the field itself as to topography and drainage makes the comparisons between the organic and the conventional systems somewhat biased and unreliable, these results should not be generalised to cover the overall question of yield level in organic cropping.
\end{abstract}

Index words: cropping systems, extensive organic farming, Hordeum vulgare, Triticum aestivum, Avena sativa

\section{Introduction}

Organic agriculture has become a major topic in public discussion about the future of agriculture. The demand for organically grown products is increasing and more and more farmers are willing to convert from conventional to organic farming. Owing to these 
developments, the question of how the conversion to organic farming affects crop yields and yield quality has arisen.

There are several ways of seeking answers to the above question. A farmer who is already practising organic farming may compare the results he has obtained on his own farm before and after the conversion. Variation e.g. in climatic conditions from one year to another, however, makes this comparison uncertain, and the differences between locations (and farmers) make it difficult to generalize. Collection of data from a greater number of farms might make the results more reliable.

Another possibility is to study existing farms, where cultivation is organic or conventional, contemporarily. One example is the Swedish comparison between bio-dynamic and organic farms on the other hand, and conventional farms, on the other, by PETTERSSON (1982) and Granstedt (1990). In Finland, Mela (1988) made a three year-survey on 40-48 existing organic farms, and used seven to ten conventional farms as a comparison. Such an approach maintains closeness to the 'real world', but it is not easy to find representative pairs similar enough to allow generalisation of the results.

This kind of survey may describe the situational problems presently faced, but the comparisons do not necessarely answer the questions mentioned above. Some of the variation between locations can be controlled by comparing very many farms, but only partly: only more or less succesful farms remain for comparison; the ones that failed are not included. It is difficult to distinguish the effect of farmers' skill and enviromental differences from the biological compatibility of the cropping systems on individual farms. LOCKERETZ et al. (1981) controlled this variation by means of matched pairs of fields.

In our project, traditional field experiment techniques were used to control the abovementioned confounding variations. However, economic demand, which is an essential feature to a real farm and was included in sur- veys such as MelA's, and, e.g. in the integrated farming systems of Lautenbach, Germany (El TITI \& LANDES 1988), has not been taken into account here. Nor can the decisions made be as flexible as those on a real farm. The size of plots can be increased to allow crop management on field scale, but the movement of weeds, insects, fungi, earthworms etc. from one plot to another cannot be restricted. This approach has been used often, for instance by the Agricultural Research Centre in Finland (SIPPOLA 1983) and by Dцouny (1981) in Sweden.

The problems concerning how general the answers given by this kind of experiment may be, are more thoroughly discussed by KORvA et al. (1990, in this issue). The same paper describes the cropping systems in more details. This paper gives the methods used for the yield measurements, and their results.

\section{Material and methods}

\subsection{The Experiment}

The experimental design was a modification of the randomised blocks design, where the eight treatments were nested in two groups, organic and conventional, with three replicates, as follows:

conventional cropping on

$\mathrm{A} 1=\mathrm{a}$ barley monoculture, $\mathrm{N}-\mathrm{P}-\mathrm{K}$ application

A2 $=$ a cereal production farm, N-P-K

$\mathrm{A} 3=\mathrm{a}$ diverse plant production farm, N-P-K

$\mathrm{B}=\mathrm{a}$ cattle farm, N-P-K, slurry

organic cropping on

$\mathrm{C} 1=\mathrm{a}$ plant production farm, plant material composted

$\mathrm{C} 2$ = a plant production farm, plant material not composted

D1 = a cattle farm, slurry composted D2 = a cattle farm, slurry not composted 
Half on the hectarage in the dairy cropping systems was under leys. The leys grown in the conventional systems were mixtures of Phleum pratense L. and Festuca pratensis Huds. or Lolium perenne L. Trifolium pratense $\mathrm{L}$. was added in the organic systems. Because of outwinterings of red clover in 1984 and 1985 , the second and third year leys were resown with $T$. resupinatum L., and in 1987 and 1988, they were supplemented with $T$. pratense or resown with Vicia villosa, respectively.

In the conventional systems, the normal fertiliser and pesticide applications were used. On the other hand, virtually no chemical treatments were applied to the organic ones (KoRvA et al. 1990).

\subsection{Measurements}

Field scale machinery was used. The cereals were harvested with a $10 \mathrm{ft}$ combine harvester. The yield was measured by harvesting and weighing one combine width from the centre of the plot. Samples were taken for analysis of dry matter and for further analyses. The 1000 grain weight and hectolitre weight were analysed, as were the contents of $\mathrm{N}, \mathrm{Ca}, \mathrm{K}$, $\mathrm{Ng}$ and P. In 1988, the DM and $\mathrm{N}$ accumulation in cereals was measured by clipping the above-ground parts of plants from six sample areas totalling $0.375 \mathrm{~m}^{2} /$ plot, three times during the growing season.

The yield of leys was determined in the same way by using a silage cutter $90 \mathrm{~cm}$ wide. Only $\mathrm{DM}$ and $\mathrm{N}$ were analysed from the samples. Potato yields were determined by harvesting the middle row from the plot, using a potato digger.

\section{Results and discussion}

\subsection{Years under comparison}

This section deals with the results for the different years, including those regarded in the experimental plan as the transition period, so that possible trends arising from the conver- sion to the new system could be detected. In most cases, only the differences between organic and conventional groups were statistically significant. Major within-group differences were found only in 1988; they are discussed separately. The grain and nitrogen yields were calculated with a logarithmic transformation, owing to the dependence between the residual variance and yield. All of the quality measures, plus the barley yields in 1985 , were calculated without transformation.

\subsubsection{Yields}

The yield of barley sown with clover in the organic cropping systems was $25 \%$ of that in the conventional ones, which yielded about $3 \mathrm{t} / \mathrm{ha}$ in both 1985 and 1988 . In the better years of 1983 and 1986 barley (with clover) in the organic systems yielded $50 \%$ of the barley monoculture, which then yielded $6 \mathrm{t} / \mathrm{ha}$ (Fig. 1).

The data themselves do not directly reveal whether this difference was caused by the preceding crop in the organic rotations or by the annual variation. There was probably more nitrogen in the soil after clovers than faba bean, since the biomass of the latter was clearly less than that of clovers. Still, the annual variation may have been more important.

The yields of winter wheat in organic farming were $40 \%$ of those in conventional farming. If the outwintered areas were excluded, the percentage in 1986 was 65 . Because of the flatness of the most organic plots, described by Korva et al. in this issue, such an exclusion would be fair.

The yield of organically cultivated oats + faba bean in 1987 was $40 \%$ of that in the conventionally grown comparison, pure oats. The organic oats + faba bean produced $65 \%$ of the conventional system in 1984 , but this result may have been influenced by the urea fertilisation given in the previous autumn (Fig. 2).

The organic potato stands remained open all the summer. They produced $48 \%$ of the conventional yield of $21 \mathrm{t} /$ ha in 1984, but only $37 \%$ of the $16 \mathrm{t} /$ ha obtained conventionally in 1987 (Fig. 3). In both years, the harvesting 


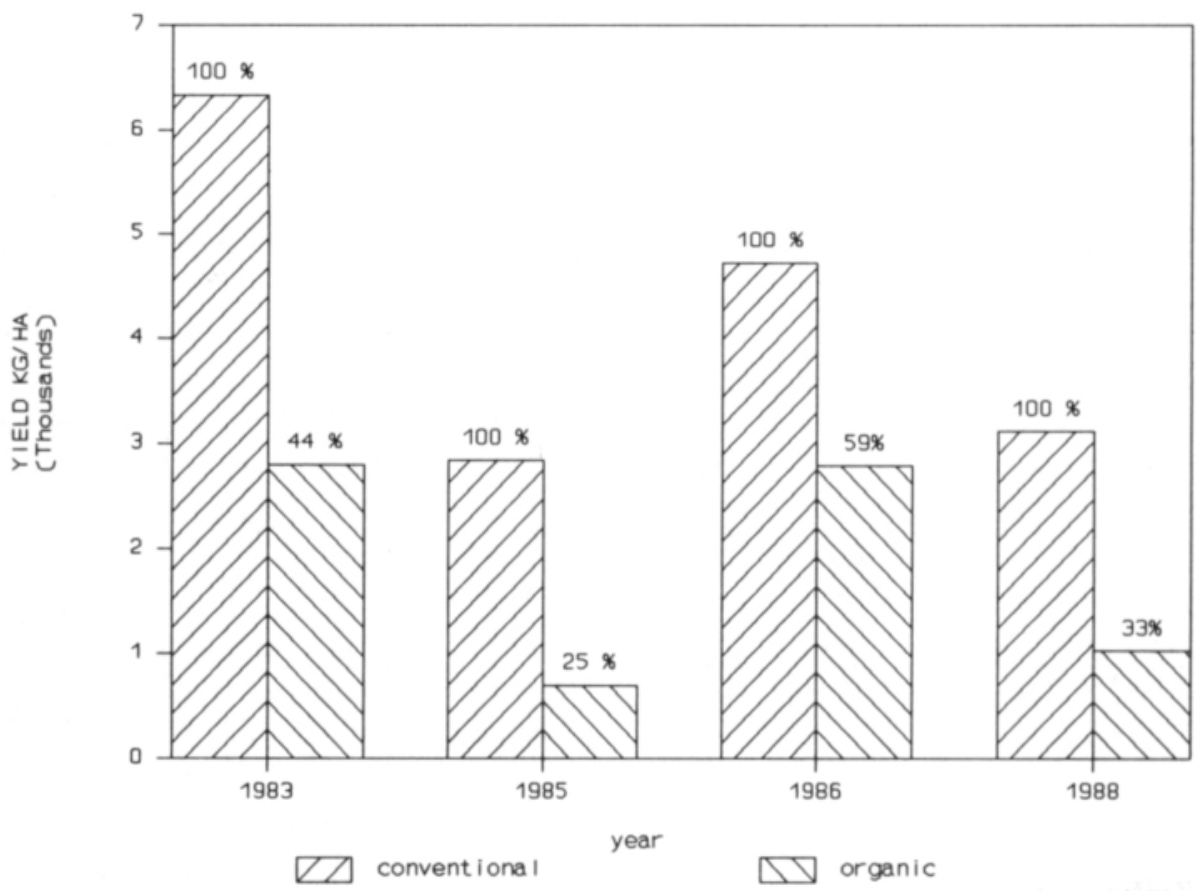

Fig. 1. Yields of barley at Suitia in 1983, 1985, 1986 and 1988 and the proportions of organic yields of conventional ones.

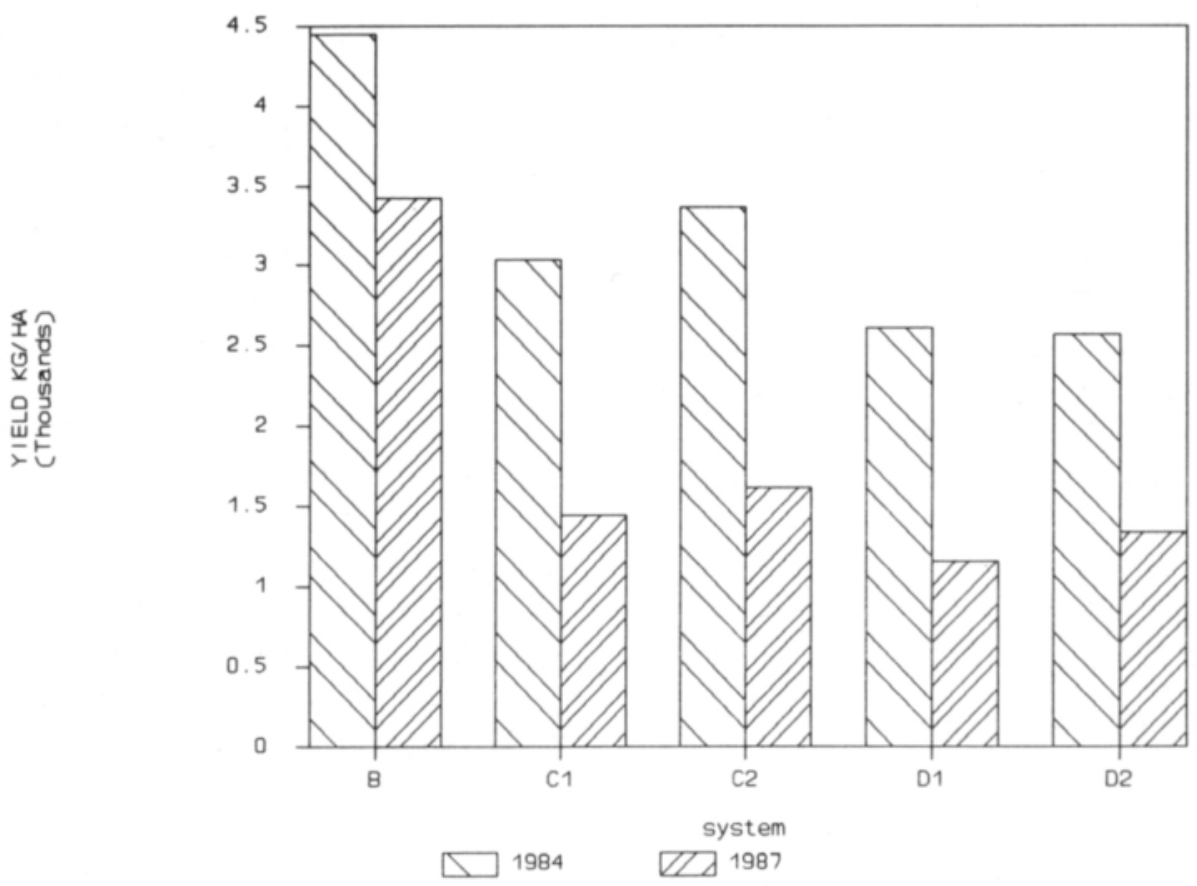

Fig. 2. Yields of oats ( + faba bean) in different cropping systems at Suitia in 1984 and 1987. 


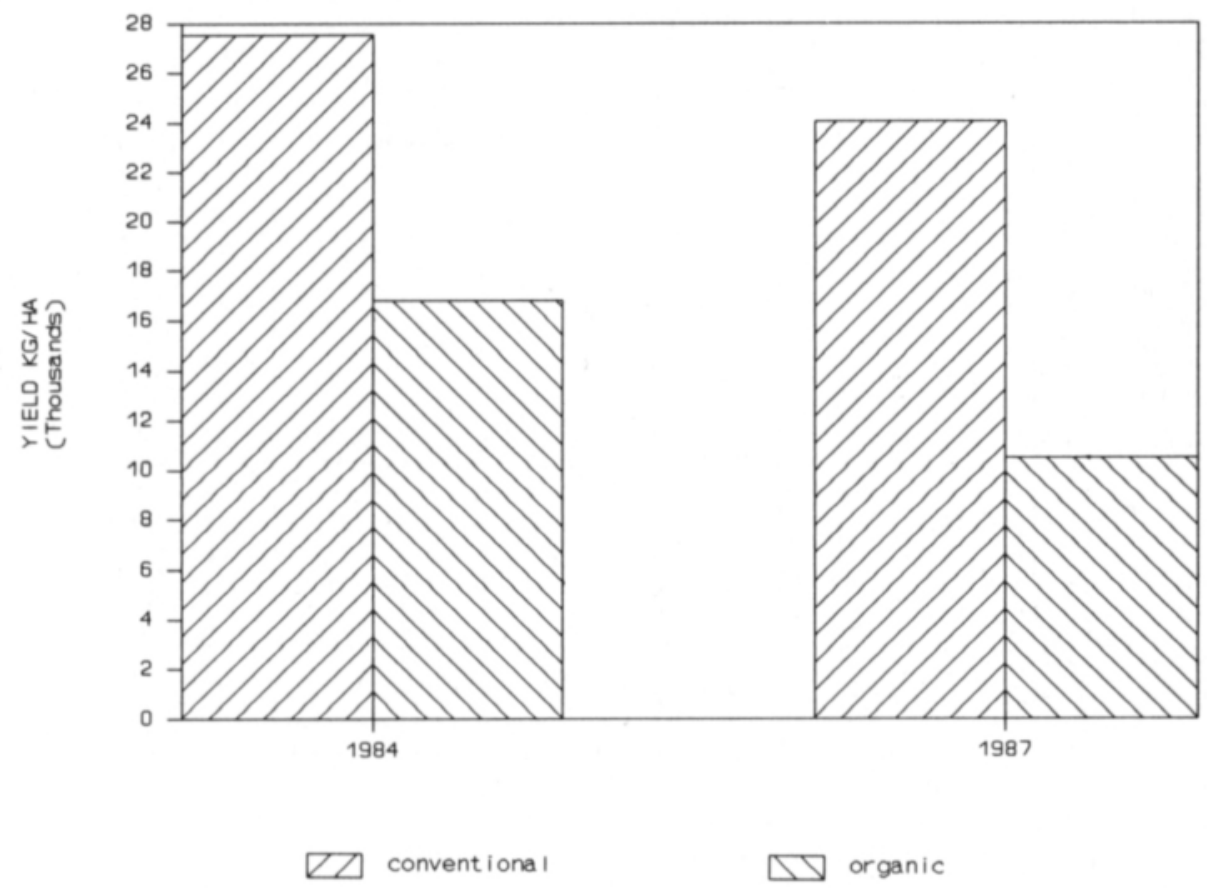

Fig. 3. Potato yields at Suitia in 1984 and 1987.

was difficult; the soil was too heavy for potato in wet summers. In 1987 for example, considerable amount of nitrogen was lost by denitrification, as measured by HEINONENTANSKI (1990, in this issue).

The yields of organically cultivated clovergrass leys equalled those of conventionally grown ones in the first year, but on the flat plots they outwintered later, because of water and ice. The annual clovers sown to replace them germinated late, and the yields were low. The conventional grass leys remained fully productive all three years. They were better situated in the field, for which reason the comparisons are not very reliable (Fig. 4).

\subsubsection{Yield quality}

In some years the $\mathrm{N}$ content of conventionally grown cereal grains was higher than that of organically grown ones. Sometimes the conventionally cultivated kernels were also bigger, but on the whole there were no significant differences (Fig. 5). Some differences in the germination ability of cereal grains have been reported by HaNNUKKaLA (1990, in this issue).

\subsection{Results for 1988, in more detail}

\subsubsection{Crop growth}

From the beginning of the growing season, the organically cultivated spring cereal plots shoved signs of a severe lack of nitrogen. The barley plants were lighter, the sprouting capacity lower, and fewer tillers were produced than in conventional cropping. The difference in the $\mathrm{N}$ content of the shoots peaked early in the tillering stage (Fig. 6). The relative difference in the biomass of barley was the greatest at the tillering phase. The pattern in the leaf area was probably similar. There was 


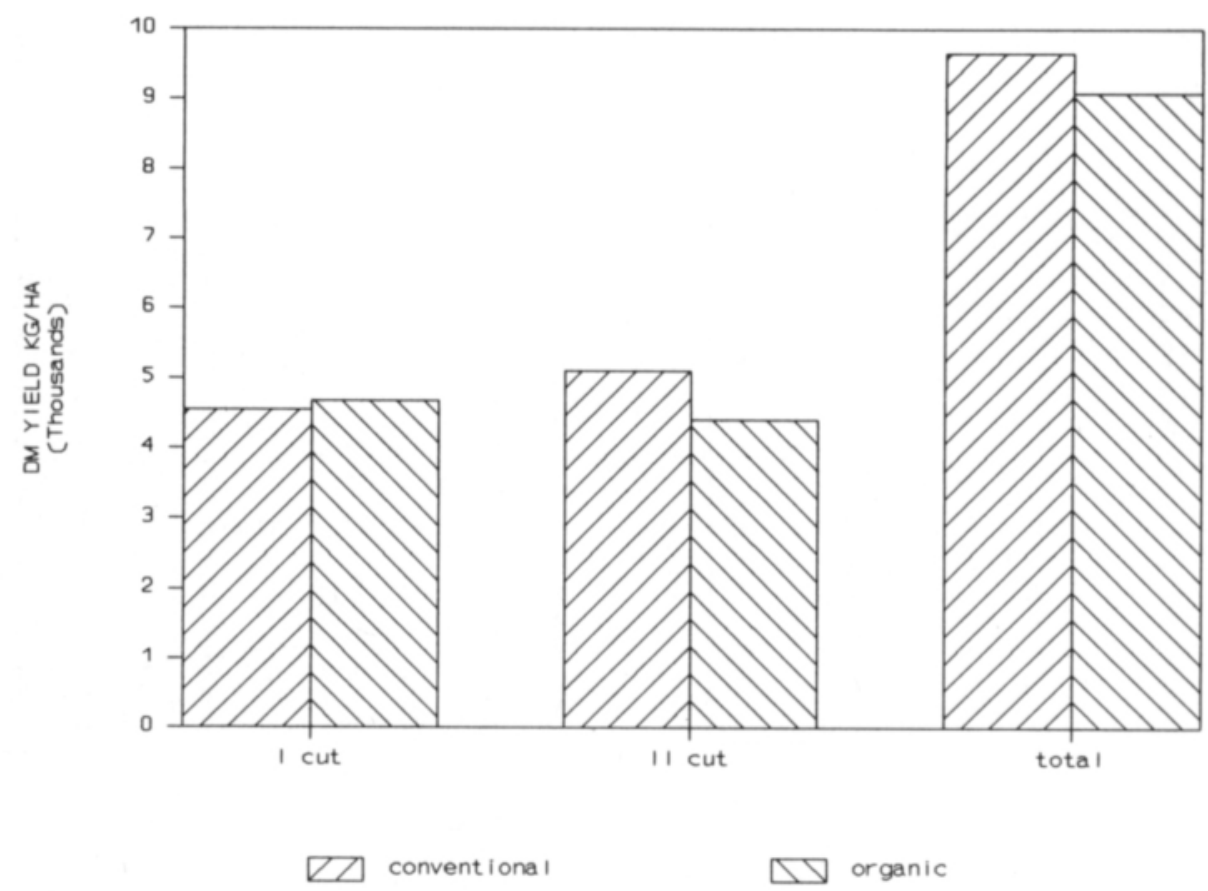

Fig. 4. Dry matter yields of first year leys at Suitia in 1986 .

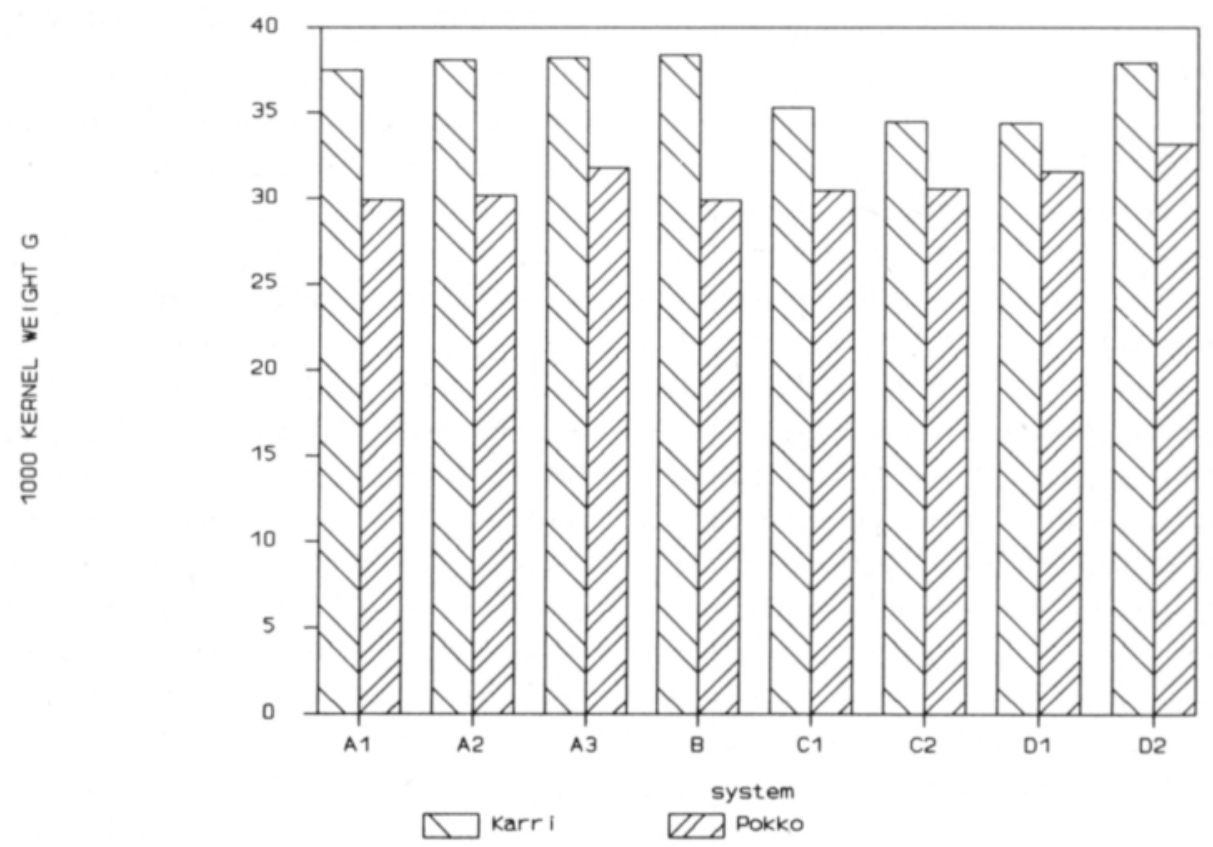

Fig. 5. Grain size of two barley cultivars in different cropping systems at Suitia in 1988. 


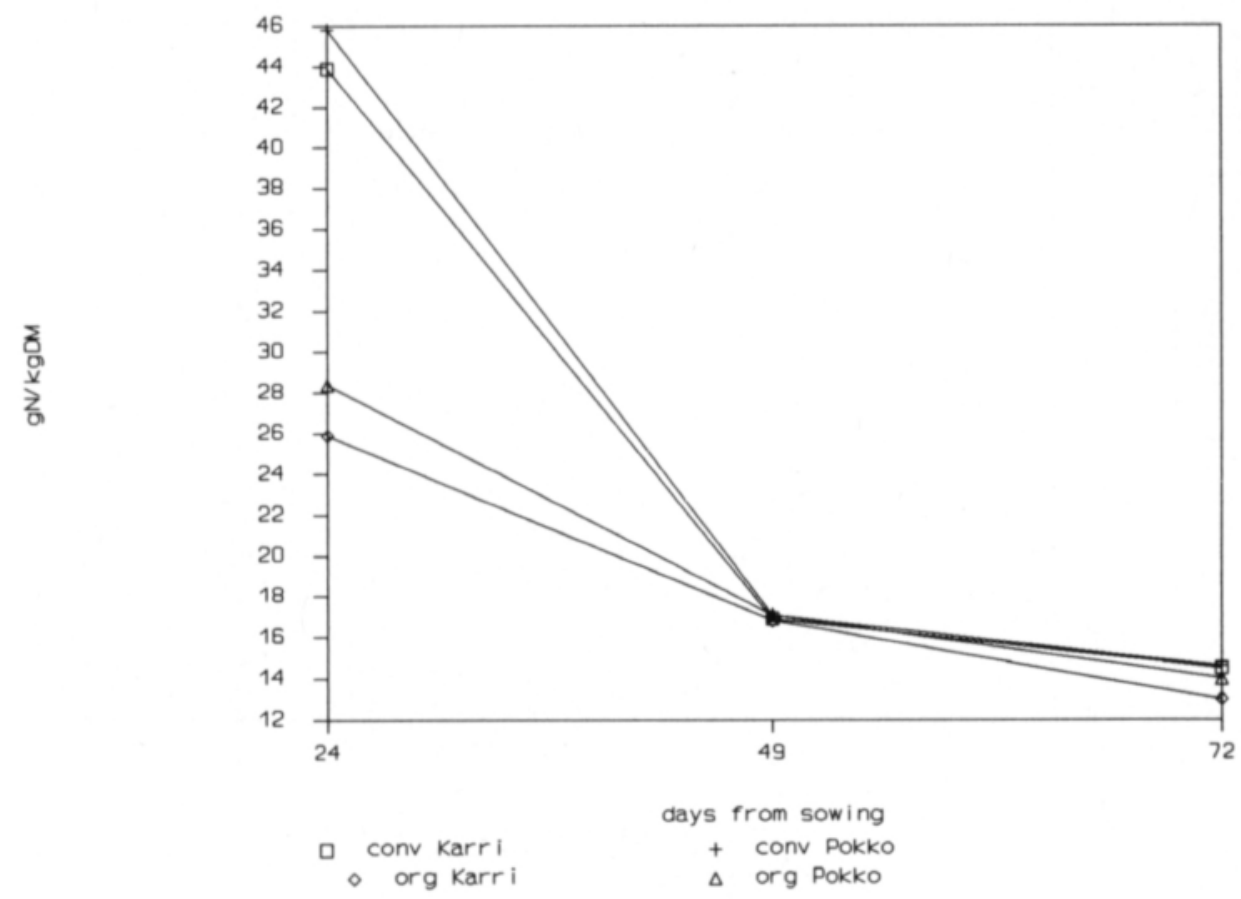

Fig. 6. Nitrogen content of barley at Suitia in 1988.

a fivefold difference in the accumulated $\mathrm{N}$ between the organic and conventional systems.

\subsubsection{Cultivars}

In 1988 in organic cropping, the barley cultivar 'Hankkija's Pokko' produced only $2 / 3$ of the yield of 'Karri', while in conventional cropping there was a relatively minor difference between the varieties (Fig. 7). There was a similar interaction in the height of the stands, the difference being less obvious in the conventional plots than in the organic ones (Fig. 8). A difference in the biomass of weeds was also found; weeds were more abundant under 'Pokko'. In the conditions prevalent in 1988 at Suitia, 'Pokko' seemed to be less suitable for 'low yield' cropping than 'Karri', a finding which agrees well with AIKASALO \& KeSALÄ's (1985) comparisons and with the results of VARIS \& LLehtiniemi 1984.

\subsubsection{Cropping systems within groups}

Differences between organic systems within the same crop were minor. Treatment with composted material did not increase the yields compared to yields obtained with green manuring that had almost no nutrients added. The system C2, which had not received any manuring for two years, and the system D2 (fresh slurry), produced significantly better than the system D1 manured with farm yard manure compost (Fig. 9). This certainly resulted from the low nitrogen content of the compost (Konva et al. 1990). The compost may have bound nitrogen rather than released it. In conventional cropping, the crop sequence diversity $\mathrm{A} 3$ increased the barley yields (Fig. 9). In the plots in phase B, potato digging destroyed the soil structure, which compensated for the expected positive effect of the crop sequence on the barley yields. 


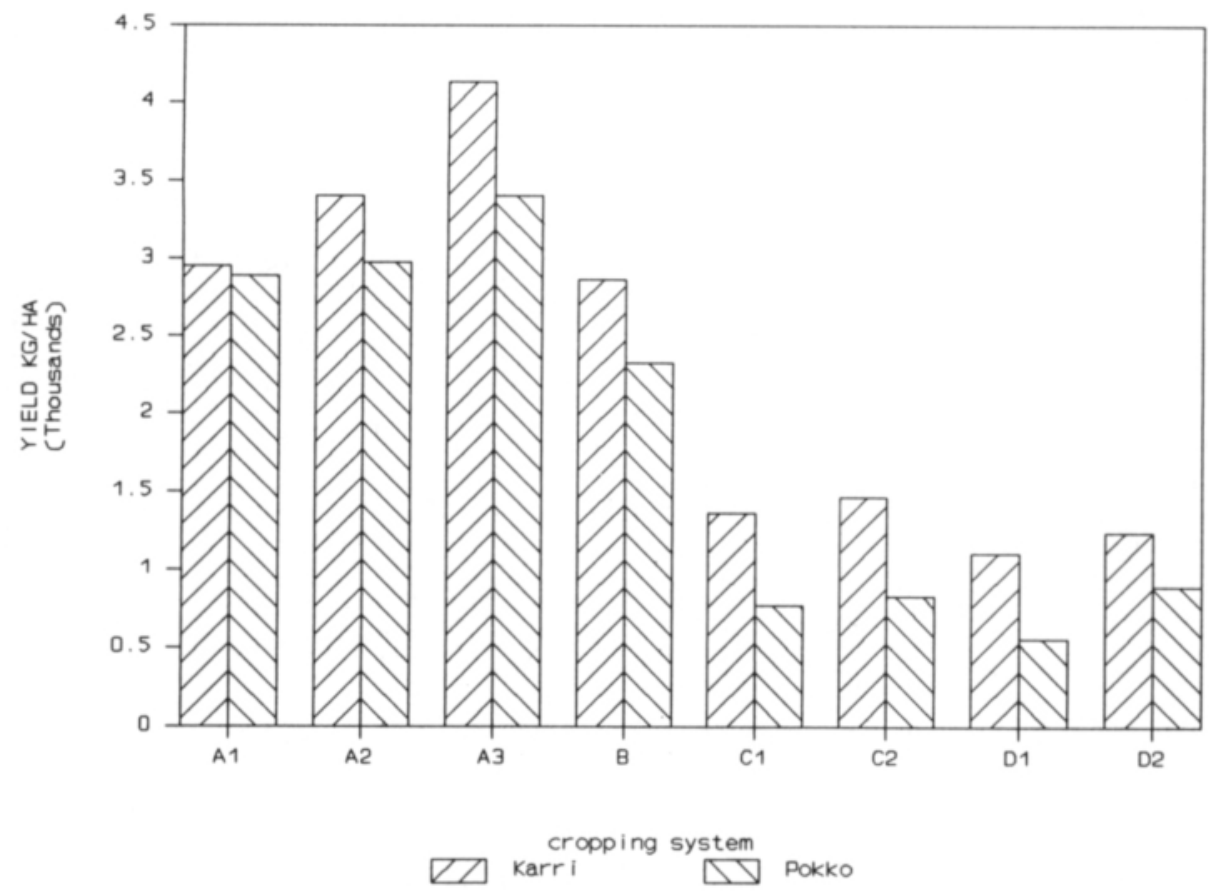

Fig. 7. Yields of two barley cultivars in different cropping systems at Suitia in 1988.

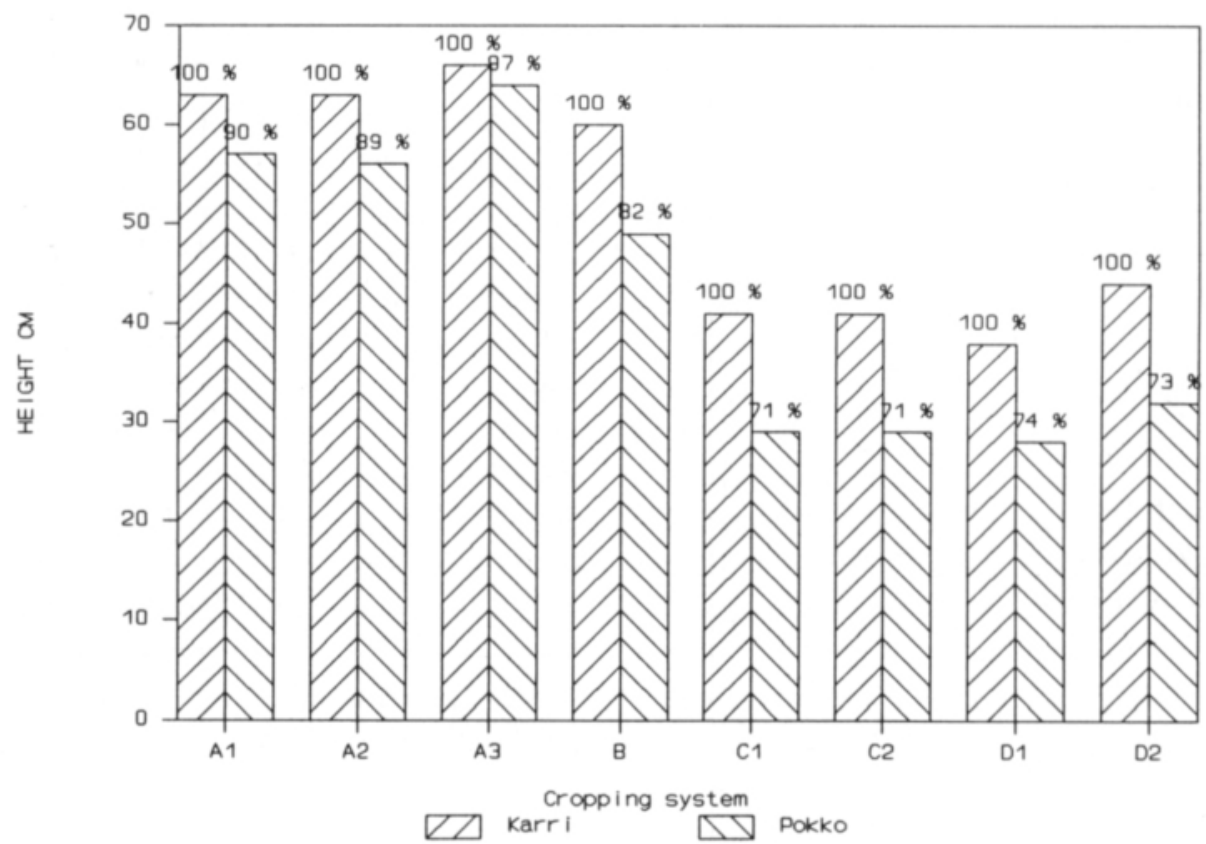

Fig. 8. Height of barley stands at Suitia on July 25, 1988 and the proportions of the cultivar 'Pokko' of the cultivar 'Karri' in different cropping systems. 


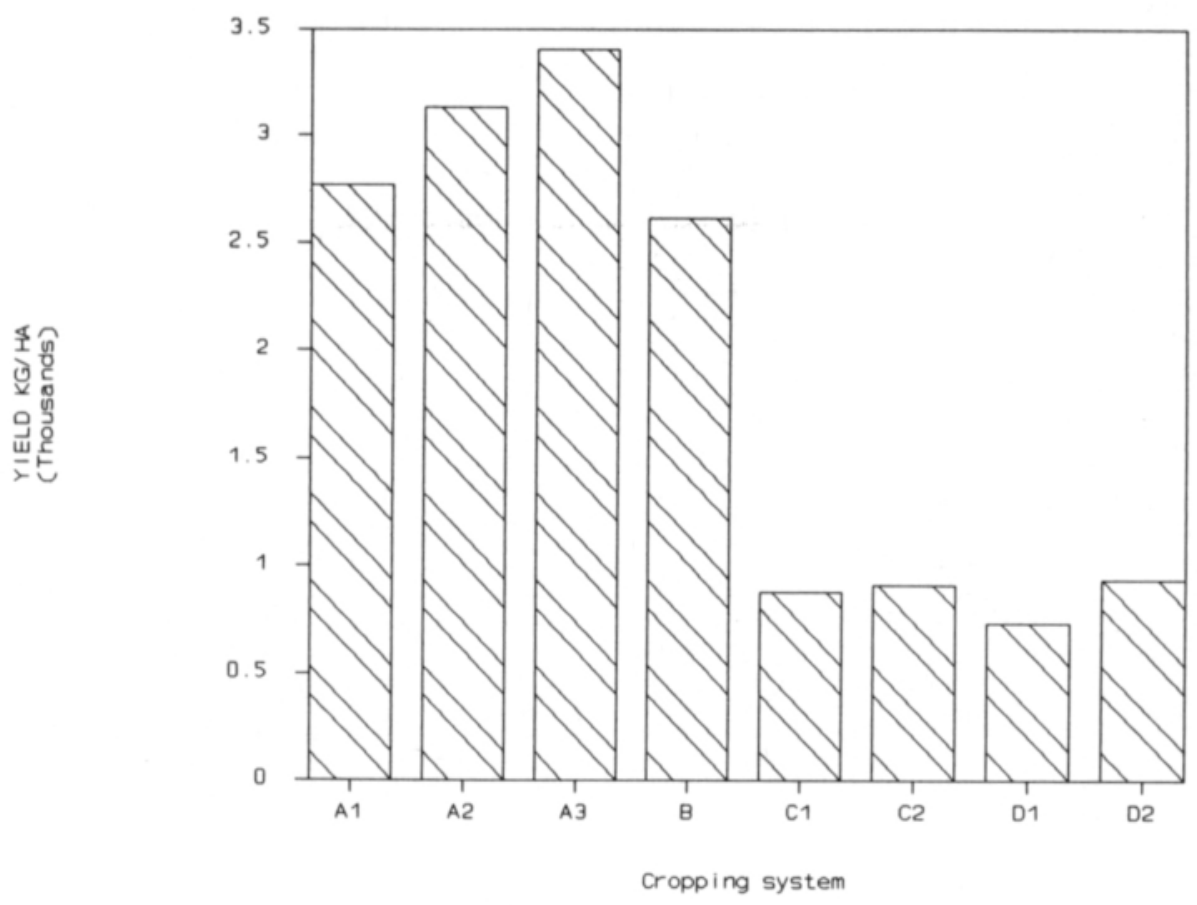

Fig. 9. Barley yields in different cropping systems at Suitia, means for 1985 and 1988.

\subsection{Organic Farming and Soil Water}

In 1987 and 1988, there was a visible difference between the inner and outer ends of the cereal plots in the flat, organically cultivated area. The inner areas were f.e. ready for sowing clearly later than the outer ones in 1988. The possible interaction between cropping system and soil wetness was checked in 1989 , as a by-product of a larger variety trial.

In each group of cropping systems, in one large plot $\left(1200 \mathrm{~m}^{2}\right)$ a variety test of barley was carried out as a part of an additional research plan. The yields of 12 plots, describing the in- teraction between cropping system and the wetness of the field are shown in this paper.

There were fivefold differences in the organically cultivated barley yields, but little or no differences in the conventionally grown ones, between occasionally wet and slightly dryer locations (Fig. 10). We suggest this to be due to an escape of $\mathrm{N}$ from the nonfertilised system in anaerobic conditions in winter. A non-fertilised system is wholly dependent on the soluble $\mathrm{N}$ released from the organic matter and stored in the soil over the winter, whereas a fertilised system gets most of its $\mathrm{N}$ from the fertiliser given in the spring. Other biological activities are also affected. 


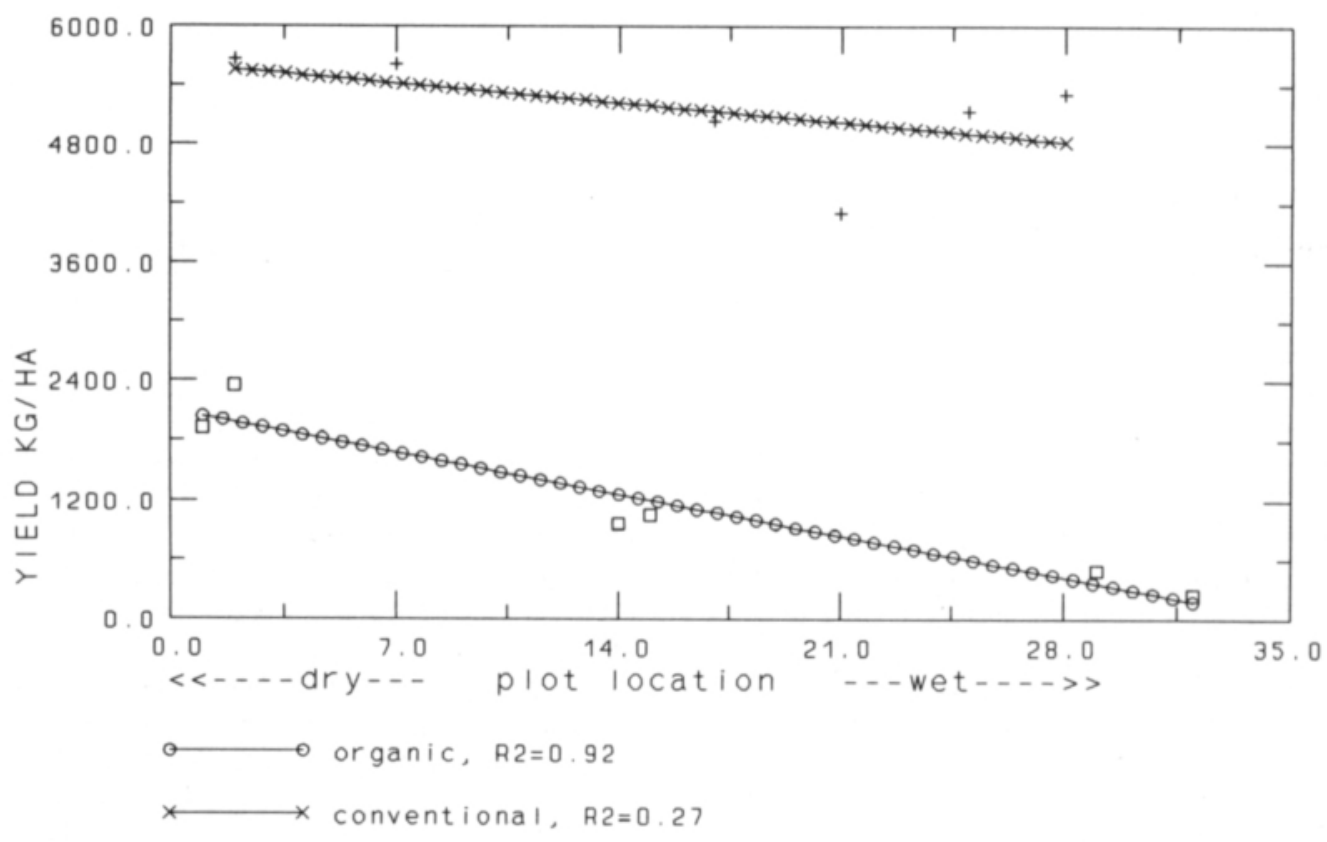

Fig. 10. Barley yields at Suitia in 1989 according to plot location.

\section{References}

Aikasalo, R. \& Kesälä, P. 1985. Ohra. Hankkijan Siemenjulkaisu 1985: 62-72.

Dıouнy, J. 1981. Alternativa odligsformer - växtprodukters kvalitet vid konventionell och biodynamisk odling. Summary: Alternative forms of agriculture quality of plant products from conventional and biodynamic growing. Inst. f. văxtodling, Sveriges Landbruksuniversit. Rapport 91. 143 p.

El Titı, A. \& Landes, H. 1988. The integrated farming system of Lautenbach: A practical contribution towards sustainable agriculture in Europe. Proc. Conf. on Sustainable Agriculture. Ohio 23.-27.9. 1988.

GRANSTEDT, A. 1990. Fallstudier av kväveförsörjning i alternativ odling. Summary: Case studies on nitrogen supply in alternative farming. Alternativ odling, Sveriges Lantbruksuniversitet. 4. 271. p.

HannukKala, A.O. \& TAPIO, E. 1990. Conventional and organic cropping systems at Suitia V: Plant diseases. J. Sci. Agric. Soc. Finl. 62: 339-347.

HeINONEN-TANSKI, 1990. Conventional and organic cropping systems at Suitia III: Microbial activity in soils. J. Sci. Agric. Soc. Finl. 62: 321-330.

HannukKala, A.O., Korva, J. \& Tapio, E. 1990. Conventional and organic cropping systems at Suitia I:
Experimental design and summaries. J. Sci. Agric. Soc. Finl. 62: 295-307.

Lockeretz, W., Shearer, G. \& Kohl, D. 1981. Organic farming in the corn belt. Science 211: 540-547.

MELA, T. 1988. Luonnonmukainen peltoviljely Suomessa. Viljelymenetelmät, rikkakasvit, peltojen viljavuus, sadot ja sadon laatu. Summary: Organic farming in Finland. Cultivation methods, weeds, soil fertility, yields, and yield quality. Helsingin Yliopiston kasvinviljelytieteen laitos. Julkaisuja 16: 1-220.

Pettersson, B.D. 1982. Konventionell coh biodynamisk odling, jămförande försők mellan två odlingssystem 1971-1979. Nordisk forskningsring, Meddelande 32. $119 \mathrm{p}$.

Sippola, J. 1983. Research project: Possibilities of food production in Finland without imported energy inputs. Swedish Univ. Agr. Sci., Inst. växtodling, Rapport 124: 89-91.

VARIS, E. \& LehtimäKı, K. 1984. Reaction of Some Spring Barley Cultivars to Mineral Nitrogen and Farmyard Manure. Proc. 5th IFOAM Conf. 1984: 99-109. Witzenhausen.

Ms received July 12, 1990 


\section{SELOSTUS}

\section{Suitian viljelyjärjestelmät \\ II: Viljelykasvien kasvu ja sadot}

\section{J. Korva ja E. Varis}

Helsingin yliopisto,

Kasvinviljelytieteen laitos

Suitian koetilalla, Siuntiossa, järjestettiin 1982-1988 viljelyjärjestelmătutkimus, josta viljelykasvien sadot mitattiin ja analysoitiin. Maaperä oli liejusavea. Tutkimuksessa oli neljä tavanomaista ja neljä luonnonmukaista viljelyjärjestelmää. Tavanomaiset järjestelmăt olivat: ohran monokulttuuri, viljanviljely, monipuolinen kasvintuotanto ja karjatila. Luonnonmukaiset olivat kasvintuotantotilan tai karjatilan järjestelmiä, joissa joko kảytettiin kompostointia tai muokattiin viherlannoitus tai lietelanta suoraan maahan.

Vuosien văliset satoerot olivat suuria ja luonnonmukaiset jărjestelmăt kärsivat huonoista vuotuisista kasvuoloista enemmän kuin tavanomaiset. Luonnonmukaisissa järjestelmissä ohran sato oli 1985 ja $198825 \%$ tavanomaisesti viljellystä, jossa satotaso oli noin $3 \mathrm{tn} / \mathrm{ha}$. Parempina vuosina, 1983 ja 1986, luonnonmukainen ohra tuotti $50 \%$ ohran monokulttuurista $(6 \mathrm{tn} / \mathrm{ha})$. Satovaihteluiden syynä luonnonmukaisten kiertojen esikasvin vaikutusta ja vuosivaihtelua on mahdoton erottaa. Syysvehnan ja kauran (+ härkäpavun) luonnonmukaiset sadot oli- vat $40 \%$ vastaavista tavanomaisista. Luonnonmukaisten järjestelmien apilanurmet tuottivat yhtä hyvin kuin tavanomaiset nurmet, kunnes jää ja vesi tuhosivat luonnonmukaiset nurmet. Luonnonmukaisesti viljellyn perunan keskisato oli $1985 \quad 48 \%$ tavanomaisesti viljellyn 21 tn:n hehtaarisadosta ja 1987 vastaavasti $37 \% 16$ tonnista.

Ohralajikkeen ja viljelyjärjestelmän yhdysvaikutus havaittiin kuivana vuonna 1988. Pokko menestyi suhteellisesti huonommin kuin Karri luonnonmukaisessa viljelyssă. Vuonna 1989, erillisessä kokeessa samalla pellolla, havaittiin maaperăn mărkyyden ja viljelyjärjestelmän vălillä yhteyttä. Maaperän vetisyys talvella näytti vaikuttavan haitallisemmin luonnonmukaiseen kuin tavanomaiseen viljelyyn. Koekentän maanpinnan muodon ja kuivatusolojen hallitsematon vaihtelu vaikeuttavat luonnonmukaisten ja tavanomaisten järjestelmien vertailua, joten nåită tuloksia ei voida yleistäă vastaamaan luonnonmukaisen ja tavanomaisen viljelyn satoeroja. 